\title{
From Sovereignty to Responsibility: An Emerging International Norm and Its Call to Action in Burma
}

\author{
Alison McCormick \\ Indiana University Maurer School of Law
}

Follow this and additional works at: https://www.repository.law.indiana.edu/ijgls

Part of the Constitutional Law Commons, and the International Law Commons

\section{Recommended Citation}

McCormick, Alison (2011) "From Sovereignty to Responsibility: An Emerging International Norm and Its Call to Action in Burma," Indiana Journal of Global Legal Studies: Vol. 18 : Iss. 1 , Article 22.

Available at: https://www.repository.law.indiana.edu/ijgls/vol18/iss1/22

This Note is brought to you for free and open access by the Law School Journals at Digital Repository @ Maurer Law. It has been accepted for inclusion in Indiana Journal of Global Legal Studies by an authorized editor of Digital Repository @ Maurer Law. For more information, please contactrvaughan@indiana.edu.

\section{$\Psi$}

JEROME HALL LAW LIBRARY

INDIANA UNIVERSITY

Maurer School of Law
Blooming ton 


\title{
From Sovereignty to Responsibility: An Emerging International Norm and Its Call to Action in Burma
}

\author{
ALISON MCCORMICK ${ }^{*}$
}

\begin{abstract}
"lOJur struggle for democracy is a struggle for our everyday life." This, in the words of long-detained pro-democracy leader Aung San Suu Kyi, describes the isolated pariah state of Burma. Under brutal military rule since 1962, Burma is still desperately trying to change its deplorable circumstances through the leadership of Suu Kyi, but continues to fail due to the regime-written "new" constitution that guarantees the regime's continued leading role in the state apparatus. ${ }^{2}$ Illegitimate elections and continued repression of the democratic opposition allow for the regime's violations of basic human rights to continue. Rights violations that include displacement, forced labor, rape, and murder-making it one of the world's most oppressive regimes. Following the devastation of Cyclone Nargis in 2008, the regime obstructed the delivery of any outside aid to its people, exacerbating the country's problems and causing the death of thousands from starvation and lack of medical attention. This led many in the international community to invoke an emerging
\end{abstract}

* Articles Editor, Indiana Journal of Global Legal Studies; J.D. Candidate, 2011, Indiana University Maurer School of Law; B.A., 2007, Indiana University. I would like to thank Professors David Williams and Timothy Waters for their very thoughtful comments and recommendations on early drafts, and Professor Williams, Executive Director, and Professor Susan Williams, Director, of the Center for Constitutional Democracy at Indiana University, for graciously allowing me to help in their tireless efforts to improve the lives of others, such as those in Burma, through democratic reform efforts. I would like to thank Caitlin Kerr, Editor-in-Chief, William Gardner, Executive Articles Editor, and Jeffrey Block, Articles Editor, for their careful edits, and my family for their constant love and support. Many of the strengths of this article are due to the assistance of those listed. Any errors or omissions are my own.

1. Gustaaf houtman, Mental Culture in Burmese Crisis Politics: aung San SUU KYI AND THE NATIONAL LEAGUE FOR DEMOCRACY app. 2, at 375 [Y23] (1999) (including excerpts from an interview with Aung San Suu Kyi).

2. Seth Mydans, Turnout Appears Light in Myanmar's Election, N.Y. TIMES, Nov. 7, 2010, available at http://www.nytimes.com/2010/11/08/world/asia/08myanmar.html.

Indiana Journal of Global Legal Studies Vol. 18 \#1 (Winter 2011)

(C) Indiana University Maurer School of Law 
international norm that recasts sovereignty as a responsibility, rather than a privilege, a doctrine entitled the "Responsibility to Protect." This Note argues that Burma represents the ideal case study for application of the doctrine, and that while the regime's appalling actions taken after Cyclone Nargis were a missed opportunity for such application, the atrocities that persist inside the country continue to help make a tangible case.

\section{INTRODUCTION}

[I]f humanitarian intervention is indeed an unacceptable assault on sovereignty, how should we respond to a Rwanda, to a Srebrenica, to gross and systematic violations of human rights?

Kofi Annan (General Assembly 2000) ${ }^{3}$

Humanitarian intervention has long been a controversial subject. The intentions of intervening nations have been doubted and the imposition on another's sovereignty questioned. But with genocide and other mass atrocities escalating in weak and failed states in the late 1980 s and 1990s, and the international community's willingness to consider intervention as a response, arguments for intervention were suddenly in vogue. Human rights violations seemed endemic and scholars eventually started writing widely about the need-and even the responsibility-for international action. The struggle to strike a balance between respecting sovereignty and safeguarding human rights began in earnest. In 2005, that struggle culminated at the United Nations' 60th World Summit, when over 150 heads of state and government adopted two paragraphs of text in the Outcome Document of the High-level Plenary Meeting of the General Assembly. These two paragraphs instituted a doctrine about much more than humanitarian intervention: the Responsibility to Protect. ${ }^{4}$ Proposed by a Canadiansponsored group, the International Commission on Intervention and State Sovereignty (ICISS), the initial concept underscored the obligation inherent in state sovereignty for every nation to protect its own people and held that for any state unwilling or unable to do so, a secondary responsibility should fall to the international community to protect

3. U.N. SeCretary-General, 'We the Peoples': The Role of the United Nations in the 21st Century 48 (2000), available at http://www.un.org/millennium/sg/report/ch3.pdf.

4. 2005 World Summit Outcome, G.A. Res. 60/1, ๆף 138-39, U.N. Doc. A/RES/60/1 (Sept. 15, 2005). 
those populations from genocide, ethnic cleansing, war crimes, and crimes against humanity. ${ }^{5}$ The doctrine outlined broad measures for "protection," including the use of military force as a valid last resort.

Yet after multiple modifications and subsequent adoptions, the doctrine has become weaker than originally proposed. Indeed, the United Nations' 2005 endorsement diluted the Responsibility to Protect to little more than existing treaty law. This narrow adoption of the doctrine leaves the institution much as it was before-without a progressive or evolving mandate to fulfill one of its core principles: the protection of human rights. More specifically, the 1945 U.N. Charter recognized the universality of human rights and the fundamental need for their protection in order to ensure international peace and security; however, the United Nations lacks robust legal tools to pursue violations of human rights. ${ }^{6}$

This Note explores how adopting a hollow version of the Responsibility to Protect, while mostly well-intentioned, does not set the stage for an aggressive examination of human rights violations. Instead, it argues, that it raises expectations without raising results. This is clearly demonstrated in the failed efforts to apply the doctrine to Burma, a country that has lived for decades under the harsh rule of a military dictatorship, which further exacerbated the country's problems by obstructing delivery of international aid following the devastation of Cyclone Nargis in 2008. Burma, therefore, is a valuable case study of how the diluted doctrine has left innocent people in peril.

First, this Note provides a brief history of the doctrine's origins and its purpose. Second, it explores the doctrine's evolution-including the differences in scope and power of the proposed doctrine by the ICISS and what was agreed to at the 2005 World Summit-and explains the parameters of military intervention. Third, this Note addresses the difficulty in adopting the doctrine in its most robust form and explains why it has been diluted. Fourth, it outlines why advocates of the doctrine have abandoned its application to Burma. Fifth, this Note maintains that Burma is the perfect case study to demonstrate how failure to adopt a stronger version of the Responsibility to Protect has placed further innocent populations in peril. In order to prevent similar rights violations, the international community should reverse the dilution of the Responsibility to Protect and adopt a bolder and more

5. See generally INT'L COMm'N ON INTERVENTION AND STATE SOVEREIGNTY, The RESPONSIBILITY TO PROTECT (2001) [hereinafter ICISS Report].

6. Konrad Raiser, The Ethics of Protection, in THE RESPONSIBILITY TO PROTECT: EthiCAl AND Theological Reflections 10, 10-11 (Semegnish Asfaw, Guillermo Kerber \& Peter Weiderud eds., 2005). 
morally acute doctrine-one that could be used to defend the rights of people as far away as Rangoon.

\section{The NEED for a NEW DOCTRINE: HuMANITARIAN INTERVENTION AND MASS ATROCITIES}

Humanitarian interventions increased in the late 1980s and early 1990s due to armed conflicts worldwide, which spurred calls for international engagement. The effects from these interventions led the U.N. General Assembly to adopt two major resolutions: GA Resolution $43 / 131$ (1988) ${ }^{7}$ and GA Resolution 45/100 (1990). ${ }^{8}$ These resolutions formed the legal cornerstone of humanitarian intervention for populations in need..$^{9}$ At the time, however, state sovereignty remained the primary consideration of how and whether to deliver assistance to populations in need, and both resolutions reaffirmed the territorial integrity of every state. In fact, the U.N. Charter prohibits countries from using force against the "political independence of any state,"10 unless for self-defense ${ }^{11}$ or when authorized by the Security Council, and expressly forbids external intervention in matters "essentially within the domestic jurisdiction of any state." 12

Even with some U.N. attention on humanitarian conflicts, albeit with an inordinate focus on sovereignty, the conflicts and resulting atrocities continued. The following are just a few examples. In the 1990 s, genocide claimed the lives of over $800,000 \mathrm{Rwandans}$ in just 100 days, while more than five million people in the Democratic Republic of Congo, Sudan, Burundi, and West Africa fell victim to "a bloody cocktail of state collapse and warlordism." 13 The people of Timor-Leste were dealt a similar fate when thousands died after an eruption of gang

7. G.A. Res. 43/131, ๆๆ 2, 5, U.N. Doc. A/RES/43/131 (Dec. 14, 1990) (explaining that while "[r] eaffirming the sovereignty, territorial integrity and national unity of States, and recognizing that it is up to each State first and foremost to take care of the victims of natural disasters and similar emergency situations occurring on its territory," the international community should respond quickly due to the importance of aid after a natural disaster or other serious situation).

8. G.A. Res. 45/100 U.N. Doc. A/RES/45/100 (Dec. 8, 1988) (recalling and reaffirming Resolution 43/131).

9. Semegnish Asfaw, Introduction, The Responsibility to Protect: Ethical and Theological Reflections (attributing these resolutions to armed conflicts as well as natural disasters).

10. U.N. Charter art. 2, para. 4.

11. Id. art. 51 .

12. Id. art. 2, para. 7 .

13. AleX J. Bellamy, Responsibility to Protect: The Global EFFort to END Mass Atrocities 1 (2009). 
violence in its capital, Dili. ${ }^{14}$ In Europe, Serbian forces systematically slaughtered more than 7,000 Bosnian Muslim males in the presence of U.N. forces. ${ }^{15}$ Atrocities have continued well into the 2000s. The Janjaweed, a group of Arab militiamen, and the government of Sudan, unleashed a "reign of terror which killed 250,000 and forced more than two million to flee."16

International leaders within the United Nations, such as Kofi Annan, and various heads of state called for action in the wake of these humanitarian crises. ${ }^{17}$ In several places, including Somalia and Kosovo, military intervention was used with varying degrees of success. Even where intervention was arguably most effective, such as in Kosovo, critics derided the use of force as lacking legitimacy, because it was carried out by North Atlantic Treaty Organization (NATO) forces and not sanctioned by the United Nations. ${ }^{18}$ This criticism was nothing new in the world of military intervention. For instance, when Vietnam militarily intervened in Cambodia in the 1970s to stop the Khmer Rouge from further acts of genocide, they experienced condemnation by the international community despite the successful end result. ${ }^{19}$ In other places, like Rwanda, world leaders opted to avoid military involvement even though thousands of civilians were being killed in brutal acts of genocide. Intervention was becoming an ad hoc practice, and the world lacked clear guidance on when it should and should not be used. But one development was clear: the paradigm of absolute state sovereignty had slowly eroded in favor of a more human-rights oriented approach, in which the basic welfare of a state's populace became the paramount concern. ${ }^{20}$

Notwithstanding this positive development, the international community's response to the mass atrocities noted above, as well as others still, has been delayed and inchoate, thus leaving innocent populations vulnerable. Despite a lack of political will, which is

14. Thomas G. Weiss, Humanitarian Intervention: War and Conflict in the MODERN WORLD 101 (2007).

15. Id. at 86.

16. BELLAMY, supra note 13 , at 1 .

17. See, e.g., U.N. SECRETARY-GENERAL, supra note 3, at 48.

18. E.g., Arkadiusz Domagala, Humanitarian Intervention: The Utopia of Just War? The NATO Intervention in Kosovo and the Restraints of Humanitarian Intervention (Sussex Eur. Inst., Working Paper No. 76, 2004).

19. Gareth Evans, The Responsibility to Protect: Moving Towards a Shared Consensus, in THE RESPONSIBILITY TO PROTECT: ETHICAL AND THEOLOGICAL REFLECTIONS, supra note 6 , at 4 .

20. Brian Barbour \& Brian Gorlick, Embracing the 'Responsibility to Protect': A Repertoire of Measures Including Asylum for Potential Victims, 20 INT’L J. REFUGEE L. 533,537 (2008). 
arguably a permanent condition of self-interested states seeking to avoid the costs and uncertainty of intervention, there are other obstacles in the way of states intervening on behalf of human rights. Removing these obstacles and increasing both political and moral pressure on states were precisely what the ICISS sought when it created the Responsibility to Protect doctrine.

\section{THE RESPONSIBILITY TO PROTECT: AN EVOLVING INTERNATIONAL NORM}

It has taken the world an insanely long time, centuries in fact, to come to terms conceptually with the idea that state sovereignty is not a license to kill-that there is something fundamentally and intolerably wrong about states murdering or forcibly displacing large numbers of their own citizens, or standing by when others do so.

Gareth Evans, President of the International Crisis Group and co-chair of the ICISS ${ }^{21}$

\section{A. A Plea to Establish a Consensus}

During debates over the legality and legitimacy of NATO's intervention in Kosovo in 1999, Secretary-General Kofi Annan argued for a consensus on how to approach conflicts between the need for humanitarian assistance and the principle of sovereignty. ${ }^{22}$ At that time he posed this question: "if humanitarian intervention is, indeed, an unacceptable assault on sovereignty, how should we respond to a Rwanda, to a Srebrenica-to gross and systematic violations of human rights that offend every precept of our common humanity?"23 In an attempt to find common ground between human rights and state sovereignty, the Canadian government established the ICISS to write a report that would help answer this question.

21. Gareth Evans, President, Int'l Crisis Grp., Address to SEF Symposium 2007: Delivering on the Responsibility to Protect: Four Misunderstandings, Three Challenges and How to Overcome Them (Nov. 30, 2007), available at http://www.crisisgroup.org/ en/publication-type/speeches/2007/evans-delivering-on-the-responsibility-to-protect.aspx.

22. Gareth Evans \& Mohamed Sahnoun, Foreword to INT'L COMM'N ON INTERVENTION AND STATE SOVEREIGNTY, THE RESPONSIBIITY to PROTECT VII, VII (2001), available at http://www.iciss.ca/pdf/Commission-Report.pdf.

23. U.N. SECRETARY-GENERAL, supra note 3, at 48. 
Twelve members of the ICISS ${ }^{24}$ authored and published a report entitled "The Responsibility to Protect" on September 30, 2001, after the entire Commission reached unanimous agreement on the doctrine..$^{25}$ The report's central conclusion was that each state has a responsibility to protect its own citizens from four categories of crimes collectively referred to as "atrocity crimes":26 genocide, ethnic cleansing, crimes against humanity, and war crimes. ${ }^{27}$ However, should a state be unable or unwilling to protect its citizens, a secondary responsibility falls on the international community to do so. ${ }^{28}$

The ICISS recognized that there should be thresholds for determining the necessity of humanitarian intervention and established several criteria for doing so. ${ }^{29}$ After acknowledging that the notion of sovereignty was not absolute, the ICISS reported that states could "no longer use the pretext of sovereignty to perpetrate human rights violations," and instead, states have an obligation to ensure the basic rights of their citizens. ${ }^{30}$ The question thus became: What should the international community do when faced with a state egregiously violating human rights? Should the country be protected from intervention based on sovereignty? ${ }^{31}$ The ICISS answered this question with a four-part explanation of the conflict between sovereignty and human rights, including an analysis of instances when intervention overrides claims of sovereignty.

As already noted, the report first produced a new way to address the controversial issue of humanitarian intervention by reframing the protection of rights as a state's obligation to its own citizens, rather than a state's decision under its sovereign authority. Second, the report changed the way sovereignty is conceptualized. Formerly understood as the right of control, the ICISS believed sovereignty implies responsibility, including the responsibility of the international

24. Some of the members include former U.S. Congressman Lee Hamilton; former Australian Foreign Minister Gareth Evans and Algerian-native, Special Advisor to the U.N. Secretary-General Mohamed Sahnoun.

25. Evans \& Sahnoun, supra note 22, at VIII, IX.

26. David Scheffer, Atrocity Crimes Framing the Responsibility to Protect, in Responsibility to Protect: The Global Moral COMPACT For the 21st CENTURY 77, 81-92 (Richard H. Cooper \& Juliette Voïnov Kohler eds., 2009) [hereinafter GloBaL MORAL COMPACT].

27. Evans \& Sahnoun, supra note 22, at VIII.

28. Id.

29. Samuel Kobia, Words of Welcome, in The ResponsibILIty to Protect: ETHICAL AND THEOLOGICAL REFLECTIONS, supra note 6 at $1,1$.

30. Semegnish Asfaw, Introduction to THE RESPONSIBILITY to PROTECT: ETHICAL AND THEOLOGICAL REFLECTIONS, supra note 6, at ix.

31. Gareth Evans, The Responsibility to Protect: From an Idea to an International Norm, in GLOBAL MORAL COMPACT, supra note 22, at 15, 19. 
community. In other words, every state's primary responsibility is to protect its citizens, but when it fails to do so, that responsibility shifts to the international community's. The third contribution was to ensure that the concept of the Responsibility to Protect was viewed as much more than military intervention, and included the responsibility to prevent these atrocities, to react to them when they do occur (using a sliding response scale, from diplomatic pressure to sanctions), and to rebuild after any intervention. The fourth contribution is arguably the most important and controversial; therefore, it is the primary subject of this Note. The ICISS's fourth contribution provided guidelines the international community should follow in cases where military intervention might be necessary. ${ }^{32}$

The guidelines for the use of force in response to grievous rights violations include four precautionary principles: (1) "right intention," by which "[ $t]$ he primary purpose of the intervention, whatever other motives intervening states may have, must be to halt or avert human suffering"; (2) "last resort," by which "[m]ilitary intervention can only be justified when every non-military option for the prevention or peaceful resolution of the crisis has been explored, with reasonable grounds for believing lesser measures would not have succeeded"; (3) "proportional means," by which "[t]he scale, duration and intensity of the planned military intervention should be the minimum necessary to secure the defined human protection objective"; and (4) "reasonable prospects," by which " $[t]$ here must be a reasonable chance of success in halting or averting the suffering which has justified the intervention, with the consequences of action not likely to be worse than the consequences of inaction." 33 In addition to the four precautionary principles, there must also be "just cause," by which there must be "large scale loss of life . . . with genocidal intent or not, which is the product either of deliberate state action, or state neglect or inability to act, or a failed state situation; or large scale 'ethnic cleansing,' . . . whether carried out by killing, forced expulsion, acts of terror or rape."34 Finally, the "right authority" must be present, which confirms that there is no better authority than Security Council authorization..$^{35}$

It is important to examine how the ICISS report addressed military intervention as compared to the much shallower version adopted at the 2005 World Summit, entitled the Outcome Document. The Outcome Document significantly changed core principles of the ICISS's Responsibility to Protect to the detriment of both failed states and

32. Evans \& Sahnoun, supra note 22, at XII.

33. Id.

34. Id.

35. Id. 
developed countries. The following are five key differences between the separate interpretations adopted:

First, under the Outcome Document, there is no formal secondary responsibility of the international community to react to the human rights violations occurring around the globe. Rather, the only responsibility of the international community is to evaluate each situation on a "case-by-case basis" and to stand "prepared to take collective action." 36

Second, in the event the Security Council fails to authorize intervention, the ICISS permits additional sources of authority to consider strategies involving collective action. ${ }^{37}$ The Outcome Document provides that only the Security Council may authorize the use of force.

Third, while the ICISS requires that a country merely prove itself "unable or unwilling" to protect its citizens before the international community takes on the responsibility to protect, the Outcome Document raises the threshold: a country must establish a "manifest failure" to protect its citizens before outside intervention is permitted. ${ }^{38}$

Fourth, the ICISS allows for a broader spectrum of actions that will permit military intervention such as "serious and irreparable harm occurring to human beings, or imminently likely to occur," as well as "large scale loss of life" or "large scale "ethnic cleansing." 39 In contrast, the World Summit's approval of military intervention is in the limited circumstances of "genocide, war crimes, ethnic cleansing and crimes against humanity." 40

Fifth, while the Outcome Document ignores any additional criteria prior to intervention, the ICISS addresses what it labeled as "precautionary principles": right intention, last resort, proportional means, and reasonable prospects. 41

Because the Outcome Document contains the crucial two paragraphs, 138 and 139, concerning the parameters of the Responsibility to Protect that were adopted at the World Summit, that version, as it currently exists, will be the focus for analysis.

36. 2005 World Summit Outcome, supra note 4, at $\rceil 139$.

37. ICISS Report, supra note 5, at 53-55 (suggesting, in paragraph 6.35 , that regional organizations and regional arrangements may be able to take action and seek ex post facto U.N. Security Council approval).

38. Bellamy, supra note 13 , at 90 .

39. ICISS Report, supra note 5 , at XII.

40. 2005 World Summit Outcome, supra note 4 , at $\ 139$.

41. ICISS Report, supra note 5 , at XII. 


\section{B. Tweaking the Findings Further}

As illustrated above, the principle of the Responsibility to. Protect has become increasingly narrow, despite the doctrine's growing institutional and popular support. In particular, the doctrine has been approved by the African Union's Constitutive Act; 42 the Secretary General's High Level Panel on Threats, Challenges, and Change; ${ }^{43}$ the 2005 U.N. World Summit; ${ }^{44}$ and later by the Security Council in a resolution on the Protection of Civilians in Armed Conflict in Resolution 1706 on Darfur. ${ }^{45}$ Rather than being adopted in full, the more than 100page ICISS report was reduced to a mere two paragraphs at the World Summit-two paragraphs that were not legally binding and that amounted to little more than existing treaty law.46 For instance, the Convention Against Genocide of 1948 already obligated states to prevent and punish crimes of genocide under international law. ${ }^{47}$

One could argue that the Outcome Document does not obligate states to do anything, since it neither requires them to do any more than what they have previously agreed to nor allows for intervention without Security Council authorization. In fact, the only doctrinal innovation of the Outcome Document is encouragement for the Security Council to interpret purely domestic atrocities as affecting international peace and security, thereby triggering Security Council jurisdiction. These glaring shortcomings demand more work on the Responsibility to Protect by the international community and will require difficult but important changes in both rhetoric and action.

\section{Why Is This Doctrine Necessary?}

Globalization has changed the face of the international system, boosting the likelihood that problems in one country, whether economic, political, or military, will affect other nations. Accordingly, the international community has a significant interest in the humanitarian problems created by violence in weak nations and failed states. Territorial disputes and armed ethnic conflicts threaten the security of other nations by spilling across international borders. While many of

42. Constitutive Act of the African Union art. 4, para. h, July 11, 2000, available at http://www.au2002.gov.za/docs/key_oau/au_act.htm.

43. G.A. Res. 59/565, I 203, U.N. Doc. A/59/565 (Dec. 2, 2004).

44. 2005 World Summit Outcome, supra note 4, at 1 138-39.

45. U.N. Secretary-General, In Larger Freedom: Towards Development, Security and Human Rights for All, I 135, U.N. Doc. A/59/2005 (Mar. 21, 2005).

46. 2005 World Summit Outcome, supra note 4, at ๆף138-39.

47. G.A. Res. 260 (III), U.N. Doc. A/ 260 (Dec. 9, 1948). 
these conflicts occur halfway around the globe and may not directly threaten any one state's interests, their cumulative effect is great. Spillover effects of atrocity crimes, however, make a doctrine such as the Responsibility to Protect necessary to contain the negative externalities of globalization. For example, genocide in country $\mathrm{X}$ can cause problems for neighboring country $\mathrm{Y}$ because of refugees pouring over the border, while country $Z$ halfway around the world is affected by the disruption of natural resources being imported from country $\mathrm{X}$.

An obvious counterpoint, however, is that many countries do not perceive the powerful globalizing effects of atrocity crimes as having the potential to affect their internal affairs. Rather, they view the atrocities as either locally containable or simply irrelevant to their interests. Yet, every nation ultimately benefits from the suppression of atrocity crimes, from the host country, whose population no longer fears mass slaughter, to every other nation that avoids economic disruption or other deleterious spillover effects. Nevertheless, even if the detriment to a state's material interests is minimal, there remains the underlying force of a moral obligation to prevent these atrocities.

Human rights have become central to international relations and law, and this doctrine represents a further development recognizing international accountability for human rights violations. The Responsibility to Protect should not be seen as a cause of "the demise of sovereignty," but rather a necessary consequence. 48 The international community, through affirmation of the principles of this doctrine established by the ICISS, could help to prevent future atrocity crimes.

Every nation benefits from the suppression of atrocity crimes, therefore, when the international community fails to intervene, the overall costs - economic and otherwise-can be extremely high. ${ }^{49}$ These costs include human lives, damage to infrastructure, deterioration of the rule of law, medical and aid expenses, and other political costs from instability. Waiting to react may only increase the costs for both the host and intervening nations. In many cases, the cost of prevention and intervention often amounts to less than the toll accumulated by inaction. ${ }^{50}$ The international community could help to prevent future atrocity crimes by affirming the principles of the Responsibility to Protect originally established by the ICISS.

48. Susan E. Mayer, In Our Interest: The Responsibility to Protect, in Global Moral COMPACT, supra note 26 , at 43,46 .

49. Id. at $48-49$.

50. Id. at 49 (noting that the "International Criminal Tribunals for Rwanda and the former Yugoslavia cost more than $\$ 100$ million per year"). 


\section{Evolution DisRuPTED: Why THE DOCTRINE HAS NOT BEEN ADOPTED IN FULL}

So why then do states remain hesitant to adopt such a seemingly attractive principle? States equivocate for several reasons, which James Pattison explains more fully in his book Humanitarian Intervention \& The Responsibility to Protect. Hesitation often stems from the idea of every nation's right to be sovereign. As Pattison notes, "the circumstances in the target state that potentially justify intervention should be limited because of a community's right of selfdetermination." ${ }^{1}$ The obvious counterpoint is that a country's selfdetermination and its right to self-governance should be limited when it is involved in perpetrating human rights atrocities within its own borders. Therefore, the right of a state to be free to govern its own people is conditional upon its treatment of those within its borders.

Another argument in favor of higher standards of proof for intervention is that those outside a state's borders may not understand the problems within those borders in such a way as to legitimize intervention. ${ }^{52}$ This argument is flawed, however, because even in situations where the human rights abuses are not glaring, there are numerous instruments that can be used to determine the scope of the crimes legitimizing intervention. Still, others argue that intervention "contravenes a state's fiduciary obligations to its citizens" by using the state's resources to help those outside of its borders. ${ }^{53}$ As previously suggested, intervention may not only be beneficial to the target state, but also to other states less directly affected.

Pattison also mentions the need for stability in the international order and that interventions may disrupt this stability. ${ }^{54}$ This argument assumes that every intervention has the potential to undermine that stability in a dramatic fashion, while ignoring the counterargument that an international order that permits atrocities to continue unnoticed is hardly an order, much less a stable one, at all. ${ }^{55}$

The most reasonable basis for maintaining a high bar for humanitarian intervention, Pattison argues, is a state's likelihood of success. ${ }^{56}$ States remain hesitant to intervene due to concerns, such as a lack of resources, which are determinant for staging a successful

51. James Pattison, Humanitarian Intervention and the Responsibility to PROTECT: Who ShouLd INTERVENE? 20 (2010).

52. Id at 20-21.

53. Id. at 22 .

54. Id.

55. Id.

56. Id. 
intervention. An intervening state must have sufficient resources and capabilities to be able to do enough good to outweigh the unavoidable harms the intervention necessarily will cause. From the standpoint of developed countries, such as the United States, these assertions against adopting a stronger doctrine may seem insubstantial. Powerful nations are more likely to support affirmation through the United Nations, because international cooperation will reduce costs while allowing them to remain influential. To leaders in developed countries such as the United States, U.N. ratification of this doctrine could be viewed as honorable because the doctrine places the most fundamental human right, "the right to life," at the forefront of the international system. ${ }^{57}$

Additionally, civil support for the Responsibility to Protect would most likely be broad in the United States. A 2008 Chicago Council on World Affairs survey showed that Americans overwhelmingly support humanitarian interventions to prevent atrocity crimes. In fact, $69 \%$ of Americans support the use of U.S. troops to stop a government from committing genocide and killing large numbers of its citizens, and $62 \%$ favor being part of an international peacekeeping force to stop the killing in Darfur. ${ }^{58}$ Further still, 73\% favor giving the United Nations the authority to investigate violations of human rights in other countries, 59 and $67 \%$ think the "UN Security Council has the responsibility to authorize the use of military force to protect people from severe human rights violations such as genocide, even against the will of their own government."60 Moreover, if a majority of Americans support the most controversial principle of the Responsibility to Protect, military intervention, then it can be presumed that a majority of Americans will also support less costly measures, such as economic sanctions. ${ }^{61}$ It is clear that the United States has the civil support from its own citizens to affirm the Responsibility to Protect and therefore, has the ability to garner the political will to help make it an international policy rather than a mere concept.

Weak developing states should support affirmation of the Responsibility to Protect through a U.N. treaty because it will help to ensure that more powerful nations will not unilaterally intervene based on their own self-interests. In fact, if policymakers in developed nations

57. Lee Feinstein \& Erica De Bruin, Beyond Words: U.S. Policy and the Responsibility to Protect, in Global MoRal CoMPACT, supra note 26, at 179, 188.

58. The Chi. Council on Global AfFairs, ANxious Americans SeEK a New DIRECTION IN UNITED STATES FOREIGN POLICY 23 (2009), available at http://www.thechicagocouncil.org/UserFiles/File/POS_Topline\%20Reports/POS\%202008/20 08\%20Public\%200pinion\%202008_US\%20Survey\%20Results.pdf.

59. Id. at 13 .

60. Id. at 14 .

61. Mayer, supra note 48 , at $47-48$. 
formally embraced the Responsibility to Protect, that would also mean embracing the tenets of the doctrine that insist on multilateral cooperation and the use of force as a last resort, potentially mitigating outside fears that the concept would be used to justify imperialist actions. According to the doctrine's guidelines, armed intervention would not occur unless all multilateral avenues had failed and the atrocity crimes persisted.

The doctrine is also rooted in international law, and therefore, it should be more acceptable to developed and developing states alike. For instance, three of the four categories of crimes addressed in the doctrine, war crimes, genocide, and crimes against humanity, are international crimes recognized by the Rome Statute of the International Criminal Court. ${ }^{62}$ Furthermore, their legitimacy derives "from the jurisprudence of the international and hybrid criminal tribunals built during the 1990s."63 Thus, the doctrine has the potential to develop from an emerging norm into a rule of customary international law.

At the World Summit, the United States' opposition to the doctrine of the Responsibility to Protect stemmed partly from the requirement for peremptory Security Council authorization to intervene no matter the circumstances, while the Group of 77 (G77) supported the document only if such approval was required. ${ }^{64}$ This group of developing nations did not want any one powerful country, such as the United States, to have the ability to intervene unilaterally in the domestic affairs of another country using the doctrine as its authority. Although an understandably desired requirement, approval by the Security Council often results in deadlock for countries most in need, as was the case for Kosovo and Burma when Russia and China vetoed intervention. Certainly there is value to Security Council authorization - the creation of safeguards against unjustified unilateral action, the greater amount of resources available for intervention and subsequent rebuilding, and the determination of the legality of an intervention, for instance. ${ }^{65}$ But in cases where populations are at risk and in need of aid, such as in Burma, dependence on Security Council approval can jeopardize response efforts.

62. Rome Statute of the International Criminal Court art. 5, para. 1, July 17, 1998, U.N. Doc. A/CONF.183/9.

63. Scheffer, supra note 26 , at 80 .

64. BELLAMY, supra note 13 , at 85 .

65. Kenneth Roth, Was the Iraq War a Humanitarian Intervention? And What Are Our Responsibilities Today?, in GLOBAL MORAL COMPACT, supra note 26, at 101, 109. 


\title{
IV. TAKING RESPONSIBILITY FOR A BROKEN STATE: WHY ADVOCATES ABANDONED APPLICATION TO BURMA AND HOW TO PREVENT FURTHER DILUTION OF AN IMPORTANT DOCTRINE
}

\begin{abstract}
It is not enough merely to call for freedom, democracy and human rights. There has to be a united determination to persevere in the struggle, to make sacrifices in the name of enduring truths, to resist the corrupting influences of desire, ill will, ignorance and fear.
\end{abstract}

Aung San Suu Kyi66

In May of 2008, Cyclone Nargis hit Burma and took a devastating toll, alerting much of the world to the crimes committed by its State Peace and Development Council (SPDC) regime. Estimates held that nearly 80,000 people died and at least 50,000 more were injured.67 Following the natural disaster, the junta refused to grant access to the affected region, cutting off humanitarian aid and exacerbating the population's problems. ${ }^{68}$ Burma Campaign U.K. reported on May 15, 2008 , that "[d]espite allowing in more aid flights, foreign aid workers were yesterday told to leave the Delta region. The majority of Cyclone victims have still not received any aid, and lives are being lost every day. . . . [D]octors and medics are also being turned back by army checkpoints."69 Each day the SPDC rejected access to aid, more people died.

With such enormous administrative hurdles standing in the way of foreign aid workers, and the people of Burma left with no assistance, the call for invocation of the Responsibility to Protect had begun. A key supporter of its application in Burma was French Foreign Minister, Bernard Kouchner, who days after the Cyclone hit stated, "I again solemnly appeal to the Burmese authorities to lift all restrictions on the distribution of the aid by the most efficient channels . . . . To address human suffering, wherever it may be, is precisely what is meant by the '[R]esponsibility to

66. AUng SAN SUU KYI, FREEDOM FROM FEAR 183 (1996).

67. Burma, CLA WORLD FACTBOOK, https:/www.cia.gov/library/publications/the-worldfactbook/geos/bm.html (last visited Oct. 9, 2010).

68. Bureau of East Asian and Pac. Aff., Background Note: Burma, U.S. DEP'T OF STATE (July 28, 2009), http://www.state.gov/r/pa/ei/bgn/35910.htm.

69. China Blocking UN Responsibility to Protect Action For Burma, BURMa CAMPAIGN UK (May 15, 2008), http://www.burmacampaign.org.uk/index.php/news-and-reports/ newsstories/China-Blocking-UN-Responsibility-To-Protect-Action-For-Burma/5. 
[P]rotect' accepted by the international community ...."70 In its report, the ICISS had listed "overwhelming natural or environmental catastrophes, where the state concerned is either unwilling or unable to cope, or call for assistance, and significant loss of life is occurring or threatened," among the conditions that would give rise to humanitarian intervention. The Outcome Document, however, failed to mention application of the doctrine beyond the atrocity crimes.

More surprisingly, however, some proponents of the Responsibility to Protect refused to support its application to Burma. The problems with applying the doctrine did not arise with the principles of just cause, right intention, or proportional means. After all, it is hard to argue that there is not just cause to intervene on behalf of a devastated population that has been denied international aid after one of the worst environmental disasters ever recorded; or that the United States, France, or Great Britain did not possess the right intent while drifting offshore with aid, waiting for the regime's go-ahead for delivery. Moreover, providing aid via airdrops is certainly proportional to the devastation caused by both the Cyclone and the junta's actions. The problem, according to some scholars, arises with the latter three principles: right authority, last resort, and reasonable prospects.

A Security Council resolution, even according to the ICISS report, is the most ideal form of right authority. Without Security Council authorization, intervention may still be possible, such as NATO's involvement in Kosovo in 1999. However, the actions taken in Kosovo were supported by a majority of both its neighbors and of the world's democracies, whereas in Burma's case, even its neighbor India, the world's largest democracy, did not support international intervention. ${ }^{71}$

The principle of last resort poses many problems in an emergency. In the aftermath of an environmental catastrophe, almost nothing is more important than time; however, taking decisive action is always the most difficult decision, politically, to make. It is costly to exhaust all other options before resorting to humanitarian intervention.

Additionally, the reasonable prospects of success of "militaryprotected unilateral air drops and 'sea bridges' from those American, British and French ships" to deliver aid to people in remote areas, in which local help would be necessary for delivery, is difficult to

70. Communiqué, M. Bernard Kouchner, Minister of Foreign and European Affairs (May 8, 2008), available at http://www.ambafrance-uk.org/Bernard-Kouchner-on-Burmadisaster.html\#toutil_sommaire_2.

71. Timothy Garton Ash, We Have a Responsibility to Protect the People of Burma. But How?, THE GUARDIAN, May 22, 2008, available at http://www.guardian.co.uk/comment isfree/2008/may/22/burma.cyclonenargis. 
guarantee. ${ }^{72}$ The junta's indifference to their people's well-being should never be doubted, and the likelihood that they would continue to divert or obstruct the delivery of aid is high.

As noted by one historian and journalist:

The Responsibility to Protect has to be exercised responsibly: that is, with a careful, informed calculation of the likely consequences. I conclude that we should use every means except that of military-backed unilateralor western "coalition of the willing"-action, which has few reasonable prospects, is arguably not the last resort, and would not have right authority. This does not mean we do nothing. We have a responsibility to act by every other means available, and there are many forms of "intervention" short of the military. ${ }^{73}$

The doctrine should be exercised responsibly; however, the dilution of the doctrine and what resulted in the Outcome Document caused the international community to waiver too long in deciding whether to implement the Responsibility to Protect after Cyclone Nargis. Action was not taken in Burma precisely because the paltry two paragraphs adopted in the 2005 Outcome Document lacked concrete responsibilities and clear guidelines, allowing international leaders to evade the moral needs posed by Burma. In contrast, intervention could have been taken pursuant to the ICISS report under the following rationale: (1) there was serious and irreparable harm, as well as large-scale loss of life, occurring in Burma; (2) additional forms of authorization were available outside of the Security Council if necessary; and (3) the international community had a responsibility to intervene since the military regime was unable and unwilling to do so. The Outcome Document rendered the ICISS report impotent, preventing meaningful action from being taken. States would have had a broader, yet more specific and detailed responsibility, if the ICISS recommendations had been heeded more fully.

\section{A. Application of the Doctrine to Past Atrocities?}

Because the doctrine was diluted in such a way as to render it inapplicable to Burma following Nargis, a situation in which it should have been applied, human rights activists began to publicly unearth

72. Id.

73. Id. 
Burma's sordid past in an attempt to compel implementation of the doctrine. It became clear that Burma represents the classic case of a state whose people could be protected under international legal norms like the Responsibility to Protect, but are not. Indeed, as will be shown, the atrocities exposed in Burma fall squarely within the criteria set by the Responsibility to Protect for some form of intervention-a reality that was highlighted clearly by the botched cyclone response.

Many human rights advocates argued that if it was not legally possible to implement the Responsibility to Protect following Cyclone Nargis, then certainly it could apply to the decades of brutal rule under the military regime-through which the people continue to suffer today. After all, any discussion of atrocity crimes would be incomplete without reference to Burma. The Southeast Asian state has long suffered under the oppressive rule of military despots from General Ne Win's 1962 seizure of state power, to his defeat and the establishment of a military junta, the SPDC, in $1988 .{ }^{74} \mathrm{Ne}$ Win's totalitarian rule began a particularly brutal period for the people of Burma, who suffered food shortages and violent suppression as a result of approximately half of the country's revenues being funneled to the military. ${ }^{75}$ The Burmese people fought back by taking to the streets in opposition to Ne Win's rule in what became known as the " 8888 Uprising"; however, the regime responded quickly by killing thousands, eventually leading not only to $\mathrm{Ne}$ Win's resignation, but also to the imposition of martial law. ${ }^{76}$ In 1990 , the junta was defeated overwhelmingly in an election in favor of the National League for Democracy (NLD); however, the junta refused to relinquish power, and the NLD's leader, Aung San Suu Kyi, was placed under house arrest. Suu Kyi has been under repeated terms of house arrest, with the SPDC sanctioning her freedom most recently on November $13,2010.77$

The situation in Burma, however, remains dire. As one Burmese native explained, "the military government kills thousands of ethnic minority people and steals and destroys their land. I wish there was no hate between the Burmese and other ethnic minority groups. The regime has created the tensions and animosity for its own purpose: to rule the country forever." 78 As Indiana University law Professor David

74. Burma, supra note 67.

75. Jackie Bennion, Burma: A Political Timeline, FRONTLNE/WORLD, http://www.pbs.org/ frontlineworld/stories/burma601/timeline.htm\# (last visited Dec. 22, 2009).

76. Id.

77. Myanmar Frees Opposition Leader Aung San Suu Kyi, Los ANGELES TMMES, Nov. 13, 2010, http:/articles.latimes.com/2010/nov/13/world/la-fg-aung-san-suu-kyi-freed-20101114.

78. Voices From the Burmese Diaspora, FRONTLINE/WORLD, http:/www.pbs.org/ frontlineworld/stories/burma601/voices.html (last visited Dec. 22, 2009) (Aung Moe Win arrived in the United States on Oct. 18, 2006, and currently lives in Los Angeles). 
Williams stated before the U.S. Senate Foreign Relations Committee in September 2009, "conditions in central Burma are bad, but in the ethnic areas there is suffering on a biblical scale, in every way comparable to Darfur."79 There is no doubt that the Burmese regime is oppressive. In fact, Transparency International ranks Burma (listed as Myanmar) 178th out of 180 countries on their Corruption Perceptions Index for 2009-meaning the only countries more corrupt are Afghanistan and Somalia, with Burma falling directly behind Sudan. ${ }^{80}$ In August 2007, a group of prodemocracy activists and Buddhist monks led a peaceful protest against the regime, triggered by the junta's increase in fuel prices. In response, the regime killed thirteen people and arrested thousands more for participating. ${ }^{81}$

The intransigence of the Burmese junta is well documented. Between 1991 and 2006, the U.N. General Assembly issued fifteen resolutions against Burma, and the former U.N. Commission on Human Rights issued thirteen-all calling for the military regime to cease violating basic human rights, to release political prisoners, to recognize the 1990 election results, and to negotiate with Aung San Suu Kyi and her opposition party. ${ }^{82}$ The regime has ignored all international demands.

While the exposure of the regime's crimes was beneficial in terms of putting a spotlight on the plight of the Burmese people, it was simultaneously harmful to the Responsibility to Protect's development, as a seemingly obvious case was overlooked for application of the doctrine. This misapplication was a desperate attempt to help those in Burma, but ended up weakening the doctrine by making it appear too vague and too loose.

\section{B. A Better Burma After a New Constitution?}

The junta convened a National Convention to draft a new constitution in 2008. It quickly became clear that the effort was decidedly undemocratic after the regime began "handpicking most of the initial 702 delegates and inviting only 106 of the elected Members of

79. U.S. Policy Toward Burma: Its Impact and Effectiveness, Hearing Before Subcomm. on East Asia and Pacific Affairs of the S. Comm. on Foreign Rel, 111th Cong. (2009) (statement of David Williams, Professor at Indiana University Maurer School of Law and Executive Director of the Center for Constitutional Democracy) (hereinafter U.S. Policy Toward Burma].

80. Corruption Perceptions Index 2009, TRANSPARENCY INT'L, http:/www.transparency.org/ policy_research/surveys_indices/cpi/2009/cpi_2009_table (last visited Dec. 22, 2009).

81. Burma, supra note 67.

82. Bennion, supra note 75 . 
Parliament to participate."83 Despite the devastation from Cyclone Nargis, the SPDC continued with the scheduled national referendum on the Convention's constitution on May 10, 2008. The approved document called for elections in 2010, which the junta promised would be free and fair; however, there was serious doubt over this claim. According to one expert, "the constitution's provisions suggest that instead of being a true catalyst for lasting change, it further entrenches the military within the government and the associated culture of impunity."84 As Professor Williams noted prior to the elections, "even if the 2010 elections are free and fair, which they won't be, they won't bring about civilian rule because the constitution does not provide for it-a partially civilian government, yes, but civilian rule, no." 85 Professor Williams' predictions were exactly right-the elections "failed to meet internationally accepted standards associated with legitimate elections," with President Obama emphasizing that they "demonstrate again the regime's continued preference for repression and restriction over inclusion and transparency." 86

This type of despotic rule has come to define Burma as one of the world's worst human rights disasters. Its people have lived under an autocratic and repressive military regime for nearly a half-century. Once developing steadily thanks to its rich natural resources, Burma now has become one of the poorest countries on earth. The SPDC has committed widespread human rights abuses against ethnic minorities, and, unfortunately, U.N. resolutions condemning the regime have done very little to curb the regime's continuing rights violations. This is precisely why Burma is a powerful case study for reformation of the Responsibility to Protect. How can this doctrine ever be taken seriously if even the most serious violators fall outside of its scope?

With widespread fear of imprisonment, little economic or political freedom, endemic rape and murder, a democratically elected leader only recently released from house arrest, and a government that uses violence as its chosen form of public outreach, the people of Burma are more than qualified for protection by the international community. However, the question remains: Which actions qualify Burma as a candidate for intervention under the Responsibility to Protect doctrine formed by the ICISS and, more importantly, the doctrine as adopted at the World Summit?

83. INT'L CTR. FOR TRANSITIONAL JUSTICE, IMPUNITY PROLONGED: BURMA AND ITS 2008 CONSTITUTION 3 (2009), available at http://www.ictj.org/static/Asia/Burma/ICTJ_MMR_ Impunity2008Constitution_pb2009.pdf.

84. Id.

85. U.S. Policy Toward Burma, supra note 79 , at 2.

86. Mydans, supra note 2. 


\title{
IV. LEGAL AND MORAL RESPONSIBILITY: MAKING THE CASE FOR ACTION IN BURMA
}

\begin{abstract}
These violations have been so numerous and consistent over the past years as to suggest that they are not simply isolated or the acts of individual misbehavior by middle and lower-rank officers but are rather the result of policy at the highest level, entailing political and legal responsibility.
\end{abstract}

\section{Rajsoomer Lallah, U. N. Special Rapporteur on the Situation of Human Rights in Myanmar, $1998^{87}$}

Some of the soft-power tools of the Responsibility to Protect, such as economic sanctions, have been used or are currently in place against Burma. For instance, "the U.S. imposed an arms embargo on Burma in 1993 and then widened its sanctions [in 1997] to include all new investment. However, existing investment-including Unocal's (now Chevron's) gas project-was exempted." 88 Congress passed the Burma Freedom and Democracy Act in 2003, banning all imports from the country except for teak and gems and restricting financial transactions. ${ }^{89}$ President Obama renewed these existing sanctions against Burma in May 2009, but it is clear that little change is happening. ${ }^{90}$ Many observers believe that sanctions are not enough.

As stated previously, in order to have properly applied the Responsibility to Protect to Burma, for either past and continuing actions by the junta, or those taken following Cyclone Nargis, pursuant to the Outcome Document, one must first have demonstrated that the SPDC has committed one of the four categories of atrocity crimes: genocide, ethnic cleansing, war crimes, or crimes against humanity.

Several NGOs have invoked application of the doctrine to Burma for decades of past crimes committed by the junta. ${ }^{91}$ Crimes against

87. U.N. Secretary-General, Report of the Special Rapporteur on the Situation of Human Rights in Myanmar, I 59, U.N. Doc. A/53/364 (Sept. 10, 1998) (prepared by Rajsoomer Lallah, Special Rapporteur on the Situation of Human Rights in Myanmar).

88. Overview of Burma Sanctions, BBC NEWS (Dec. 18, 2009), http://news.bbc.co. $\mathrm{uk} / 2 / \mathrm{hi} /$ asia-pacific/8195956.stm.

89. Id.

90. White House Press Release, President Barack Obama (May 15, 2009), available at http://www.whitehouse.gov/the-press-office/message-president-and-notice-regardingburma.

91. See The Crisis in Burma, InT'L COAL. FOR THE RESPONSIBILITY to PROTECT, http://www.responsibilitytoprotect.org/index.php/crises/crisis-in-burma (last visited Oct. 3, 2010) (noting that Fédération Internationale des Droits de l'Homme invoked the doctrine 
humanity, as defined in Article 7 of the Rome Statute, ${ }^{92}$ are perhaps the most obvious example of Burma's violation of international law and thus, the clearest road to applying the doctrine. The systematic rights violations perpetrated against the Burmese people are sufficient to meet the statute's definition. Indeed, it is well established that the junta is responsible for the murder, displacement, imprisonment, and rape of thousands of ethnic minorities within Burma, making violations under the Rome Statute relatively straightforward to prove.

in an October 2007 press release, the United Nations Association of the United States of America issued an article by Barbara Cossette invoking the doctrine; Jonathon Aitken, Honorary President of the international human rights organization Christian Solidarity Worldwide wrote an op-ed article in May 2009 calling on the United Nations to invoke the norm; over sixty British Members of Parliament signed an Early Day Motion urging the United Nations to apply the Responsibility to Protect; and in 2009, a conference entitled "An International and a Norwegian Responsibility to Protect-Crimes against Humanity in Burma?" was organized by the Norwegian Parliament's support group for Burma, Norwegian Church Aid, the Norwegian Burma Committee, the International Peace Research Institute, Oslo, the Norwegian Baptist Union and the Oslo Center for Peace and Human Rights).

92. Rome Statute of the International Criminal Court art. 7, para. 1, July 17, 1998, U.N. Doc. A/CONF.183/9. The Rome Statute of the International Criminal Court was adopted in July 1998 and came into force in July 2002. It is an articulation of many of modern principles of international criminal law. The statute reads:

For the purpose of this Statute, "crime against humanity" means any of the following acts when committed as part of a widespread or systematic attack directed against any civilian population, with knowledge of the attack:

(a) Murder;

(b) Extermination;

(c) Enslavement;

(d) Deportation or forcible transfer of population;

(e) Imprisonment or other severe deprivation of physical liberty in violation of fundamental rules of international law;

(f) Torture;

(g) Rape, sexual slavery, enforced prostitution, forced pregnancy, enforced sterilization, or any other form of sexual violence of comparable gravity;

(h) Persecution against any identifiable group or collectivity on political, racial, national, ethnic, cultural, religious, gender as defined in paragraph 3 , or other grounds that are universally recognized as impermissible under international law, in connection with any act referred to in this paragraph or any crime within the jurisdiction of the Court;

(i) Enforced disappearance of persons;

(j) The crime of apartheid;

(k) Other inhumane acts of a similar character intentionally causing great suffering, or serious injury to body or to mental or physical health. 
According to the Harvard Law School International Human Rights Clinic's report on Burma, there have been "epidemic levels of forced labor in the 1990s, the recruitment of tens of thousands of child soldiers, widespread sexual violence, extrajudicial killings and torture, and more than a million displaced persons." "93 "The report finds that UN bodies have indeed consistently acknowledged abuses and used legal terms associated with these international crimes, including for example that violations have been widespread, systematic, or part of a state policy."94

In light of the numerous and consistent reports of widespread human rights abuses by the junta, there is a prima facie case of international criminal law violations. ${ }^{95}$ But in order to legally establish that crimes against humanity have taken place, and thus establish a component of Responsibility to Protect criteria, several steps must be taken.

First, it must be established that a "prohibited" or an "enumerated" act has taken place. ${ }^{96}$ Second, such an act "must take place within a particular context, which is defined by the 'chapeau' or common elements of a crime against humanity or war crime."97 For instance, rape is a prohibited act, but not all acts of rape constitute a crime against humanity unless the common elements are present, such as whether it is widespread or systematic. "To establish that a crime against humanity has been committed, the act of [rape] must also meet the specific elements of this prohibited act." 98 The common elements of a crime against humanity are as follows:

(1) There must be an "attack"; (2) the attack must be "directed against" a "civilian population"; (3) the attack must be "widespread or systematic"; (4) the conduct of the perpetrator must be "part of" such an attack; and (5) the perpetrator must have "knowledge" that, or intended that, his or her conduct is part of such an attack. ${ }^{99}$

Analysts contend that the SPDC's actions have met (many times over) the Rome Statute's standards for crimes against humanity.

93. InT’L Human Rights CliniC at HaRvard Law SCH., Crimes in BuRMa III (2009), available at http://www.law.harvard.edu/programs/hrp/documents/Crimes-in-Burma.pdf (analyzing and synthesizing the United Nations reports documenting human rights abuses in Burma).

94. Id. at 2 .

95. Id. at $2-3$.

96. Id. at 23 .

97. Id.

98. Id. at 24 .

99. Id. at 24-25. 
Between 1992 and 2008, the U.N. General Assembly issued resolutions consistently identifying human rights violations occurring in Burma, including "forced displacement, sexual violence, extrajudicial killings, and torture." 100 According to the Special Rapporteur on the Situation of Human Rights in Myanmar, "[a]s of November 2006, the total number of internally displaced persons (IDPs) who have been forced or obliged to leave their homes and have not been able to return or resettle and reintegrate into society is estimated to be at least 500,000."101 Much of this displacement is due to armed conflict in Burma, and many of these displaced peoples have sought asylum across the border in Thailand.

According to the report by the Harvard Law School International Human Rights Clinic, these acts of forced displacement could constitute crimes against humanity prohibited by Article $7(1)(d)$ of the Rome Statute. ${ }^{102}$ While this clinic is not the official arbiter of Responsibility to Protect interventions, the point is that there are groups of scholars outside the United Nations that, through reports such as this, could make U.N. decision makers aware of atrocities that are occurring or are likely to occur around the globe. This would bolster a significant part of the doctrine, that of prevention, by helping the United Nations to establish an "early warning capability" by producing accurate and reliable information regarding the "incitement, preparation, or perpetration of the four specified crimes and violations." 103

As Secretary-General Ban Ki-moon stated in his report, "[a] reasoned, calibrated and timely response could involve any of the broad range of tools available to the United Nations and its partners." 104 These tools "include pacific measures under Chapter VI of the Charter," which would be carried out by the Secretary-General or intergovernmental organs, "coercive ones under Chapter VII," which must be authorized by the Security Council, and "collaboration with regional and subregional arrangements under Chapter VIII. The process of determining the best course of action, as well as of implementing it, must fully respect the provisions, principles, and purposes of the [U.N.] Charter."105 Articles 10 through 14 offer various functions for the General Assembly, as does the

100. Id. at 37 .

101. Special Rapporteur on the Situation of Human Rights in Myanmar, Implementation of General Assembly Resolution 60/251 of 15 March 2006 Entitled "Human Rights Council," I 54, U.N. Doc. A/HRC/4/14 (Feb. 12, 2007).

102. IN'T'L HUMAN RIGH'TS CLINIC AT HARVARD LAW SCH., supra note 93, at 48.

103. U.N. Secretary-General, Implementing the Responsibility to Protect, If 10(d), U.N. Doc. A $63 / 677$ (Jan. 12, 2009).

104. Id.

105. Id. at \ 11(c). 
"uniting for peace" process set out in the Assembly's Resolution 377 (V). ${ }^{106}$

Furthermore, the common elements required by the Rome Statute have also been met. The U.N. documents describe the victims of forced displacement as villagers, fulfilling the requirement that the attack be directed against civilian populations. ${ }^{107}$ These attacks, according to the Myanmar Rapporteur, have been "widespread" and part of a "deliberate strategy," indicating that these acts are both widespread and systematic, which are needed to constitute a crime against humanity. ${ }^{108}$ The report further highlights that there has been a showing of force and coercion, another element needed to establish crimes against humanity. ${ }^{109}$ The junta has repeatedly issued "direct orders to civilians to flee their homes" for unjustifiable reasons, such as to separate "ethnic armed groups from their civilian populations." 110 Finally, according to the U.N. Special Rapporteur on Myanmar, Burma has failed to protect its population and suffers from a "culture of impunity" in which no one is held accountable for these acts of forced displacement.111 Other acts have also been identified that meet the standard of crimes against humanity and war crimes, including sexual violence, rape, extrajudicial killings, and torture.

But the doctrine's application today for the SPDC's actions following Cyclone Nargis would be untimely. The world community missed an opportunity to hold the regime accountable. The callous reaction by the junta in 2008 following the destruction of Cyclone Nargis caused outrage by many in the international community and led to a renewed invocation of the Responsibility to Protect. But were the actions committed by the junta, restricting the delivery of international aid and workers for over two weeks as the Burmese people were left starving, enough to apply the Responsibility to Protect? Some believed they were; however, a majority of others did not.

On May 7, 2008, French Foreign Minister Bernard Kouchner stated, "[w]e are seeing at the United Nations whether we can implement the Responsibility to Protect, given that food, boats and relief teams are there, and obtain a United Nations' resolution which authorizes the delivery (of aid) and imposes this on the Burmese government."112 Others within the United Nations, however, criticized Kouchner's

106. Id.

107. INT'L HUMAN RIGHTS ClINIC AT HARVARD LAW SCH., supra note 93, at 48-49.

108. Id. at 49 .

109. Id. at 50 .

110. Id.

111. Id. at 51 .

112. The Crisis in Burma, supra note 91. 
overzealous interpretation of the doctrine. Under-Secretary-General for Humanitarian Affairs and Emergency Relief Coordinator, John Holmes, said at the time, "I'm not sure that invading them would be a very sensible option at this particular moment. I'm not sure it would be helpful to the people we are actually trying to help." 113 Most notably, the Secretary-General's Special Adviser on the doctrine itself, Edward Luck, contended that it was a "misapplication of the doctrine" if applied to Burma following Nargis. ${ }^{114}$ The current Secretary-General, Ban Kimoon, even suggested that an extension of the doctrine to natural disasters "would undermine the 2005 consensus and stretch the concept beyond recognition or operational utility."115

The World Federalist Movement-Institute for Global Policy established the Responsibility to Protect-Engaging Civil Society (R2PCS) project in 2003 in an effort to advance the doctrine so that governments and the international community are better able to protect populations from genocide, war crimes, crimes against humanity, and ethnic cleansing. The R2PCS project issued two statements following Nargis concerning the potential application of the doctrine. In the initial statement, R2PCS advocated against application of the Responsibility to Protect because it was unclear that the regime's actions constituted one of the four crimes covered by the doctrine. The project announced that "[a]lthough reports indicated that the regime in Burma had failed to protect its populations and was actually obstructing aid, the Responsibility to Protect, as adopted in the World Summit Outcome Document from 2005, does not provide for the Security Council to act on the basis of neglect and obstruction."116 This statement was later revised, and R2PCS suggested that because the international community has a responsibility not only to react to atrocities but also to help prevent them, application of the doctrine may be possible if it could be shown that the junta's actions would lead to the commission of atrocity crimes. ${ }^{117}$ The R2PCS project maintained that while military intervention could be used, albeit only as a last resort, this was not in the best interests of the Burmese population.

This much is clear: the Burmese regime has committed atrocities that are consistent with crimes against humanity and, in doing so, has failed to protect its own people. So, what can be done? The situation in Burma clearly is of the kind for which a properly constituted Responsibility to Protect doctrine, if binding, would be designed. The

113. Id.

114. Id.

115. U.N. Secretary-General, supra note 103, at I 10(b).

116. The Crisis in Burma, supra note 91.

117. Id. 
international community, per the diluted doctrine of the Responsibility to Protect under the Outcome Document, can choose to take decisive action to defend the people of Burma from further human rights violations and turn the Responsibility to Protect into a binding principle. Perhaps first and foremost, the International Criminal Court (ICC), under the Rome Statute, can obtain jurisdiction over the situation in Burma by U.N. Security Council referral to the Prosecutor under its Chapter VII powers of the U.N. Charter, as jurisdiction is not automatic since Burma is not party to the Rome Statute. ${ }^{118}$ But common sense would hold that this is unlikely. Both Russia and China, members of the U.N. Security Council, maintain relations with the Burmese government and would frustrate efforts to refer the regime to the ICC for possible prosecution. Moreover, the United Nations' weak embrace of the Responsibility to Protect would make the organization, at this point in time, an improbable source for action invoked in the name of Responsibility to Protect principles.

If force is the last resort, it should not be discarded out-of-hand because of a lack of U.N. Security Council approval under the current Responsibility to Protect paradigm. This line of reasoning has resulted in the death of thousands, if not millions, of innocents in the past. Instead, U.N. Member States should make every effort to reach an international consensus on a response strategy, but should not need permission to intervene if consensus fails in a situation comparable to a Rwanda or a Darfur. The case against the Burmese junta is clear, and an unambiguous Responsibility to Protect strategy should be followed to prosecute it.

Some U.N. leaders, such as Secretary-General Ban Ki-moon, believe that the United Nations should and will bolster its commitment to the Responsibility to Protect. In fact, Ban Ki-moon released a report in January 2009 entitled "Implementing the Responsibility to Protect," in which he explains, through a three pillar approach, how to render the norm operational. ${ }^{119}$ The three pillars, which include (1) the protection responsibilities of the state; (2) international assistance and capacity building; and (3) timely and decisive response to prevent and halt genocide, ethnic cleansing, war crimes, and crimes against humanity, ${ }^{120}$ are equally important; no pillar is assumed to be more important than another. ${ }^{121}$ His recommendations include a gathering of the General Assembly to discuss how to further develop and commit to the doctrine

118. Rome Statute of the International Criminal Court art. 13(b), July 17, 1998, U.N. Doc. A/CONF.183/9.

119. U.N. Secretary-General, supra note 103, at I 11(a)-(c).

120. Id.

121. Id. 
since its "continue[d] consideration" was part of the Outcome Document's mandate. ${ }^{122}$ But once again, the U.N.-Responsibility to Protect paradigm remains weak, and the postponement of its application to situations like Burma has harmful effects on innocent populations. No patent case of human rights violations should have to wait until the United Nations is capable of responding.

At the end of the day, maintaining peace is a collective interest, the costs of which should be shared by all. That is why adoption of a fuller and stronger Responsibility to Protect by the United Nations and all U.N. member nations is ideal and preferable. But if the international community cannot come to a better consensus on the Responsibility to Protect than the weak declarations that have been made so far, other nations should bear the burden to uphold the doctrine, unilaterally even, if required. This has the dual benefit of (1) ensuring that the doctrine's principles will be upheld regardless of the circumstances, and (2) compelling other states to work more swiftly toward consensus out of a desire to avoid having one nation exercise a preponderance of authority in situations necessitating Responsibility to Protect application.

\section{CONCLUSION}

Today, with globalization increasing the likelihood that problems in one country will cause problems-economic, political, or otherwise-in another country halfway around the world, every nation has a greater interest in their resolution. In 2005, the international community made a commitment to hold states accountable for their actions affecting their populations. Should any state engage in the commission of atrocity crimes or fail to protect its own citizens from infliction of them, it is the duty of the international community to help prevent, react, and rebuild pursuant to the doctrine of the Responsibility to Protect. Unfortunately, the doctrine has been diluted to a shallow commitment, resulting in a failure to implement it in circumstances for which it arguably was designed.

It is hard to imagine how forced displacement, burning villages, raping women, and systematically slaughtering thousands of Burmese people is not enough to apply the Responsibility to Protect. All necessary elements have been established to demonstrate the junta's decades-long engagement in the commission of crimes against humanity, which normally would mandate application of the Responsibility to Protect. Despite the clear moral imperative to act, the

122. Id. at $\{1$ (quoting 2005 World Summit Outcome, supra note 4 , at $\rrbracket 139$ ). 
current vague consensus on the doctrine reached at the 2005 U.N. World Summit has allowed discussions about international actions against the SPDC to be held hostage both by states that consider themselves allies of the regime and by advocates of the doctrine that are hesitant to apply it to an imperfect situation. The actions of the junta following Nargis were, according to most scholars, too difficult to label as atrocity crimes, and these reluctant advocates fear that relying on the doctrine to justify intervention may ultimately weaken support for the doctrine itself.

This seemingly attractive principle has proved to be difficult to adopt in its full form due to concerns regarding encroachment on states' territorial integrity, unilateral intervention by powerful nations, and the requirement of absolute Security Council authorization prior to intervention. It seems apparent that U.N. Member States must continue to consider and eventually embrace a revised Responsibility to Protect paradigm.

Even if the Responsibility to Protect can only be applied per the international consensus set out in the 2005 Outcome Document, then still the military junta has manifestly failed in its responsibilities to its own people. It has been established through years of tough United States and European rhetoric that peaceful means are not enough. It just might be that crippling sanctions or even the collective use of force are the only options to stop the bloodshed and install a truly democratically elected government the people of Burma voted for twenty years ago. The international community cannot stand back when the U.N. Special Rapporteur on Myanmar writes yet another crisis summary that goes unnoticed, while the junta continues to desolate villages, rape women, recruit child soldiers, and murder its own people. The people of Burma deserve better than that. 
